University of Nebraska - Lincoln

DigitalCommons@University of Nebraska - Lincoln

Transactions of the Nebraska Academy of Sciences and Affiliated Societies

Nebraska Academy of Sciences

$10-14-2021$

\title{
Importance of woodland patches as hibernacula for gartersnakes in a prairie river floodplain of central Nebraska
}

Tony Bridger

University of Nebraska at Kearney, tony.bridger@hotmail.com

Keith Geluso

University of Nebraska-Kearney, gelusok1@unk.edu

Follow this and additional works at: https://digitalcommons.unl.edu/tnas

Part of the Behavior and Ethology Commons, and the Zoology Commons

Bridger, Tony and Geluso, Keith, "Importance of woodland patches as hibernacula for gartersnakes in a prairie river floodplain of central Nebraska" (2021). Transactions of the Nebraska Academy of Sciences and Affiliated Societies. 534.

https://digitalcommons.unl.edu/tnas/534

This Article is brought to you for free and open access by the Nebraska Academy of Sciences at DigitalCommons@University of Nebraska - Lincoln. It has been accepted for inclusion in Transactions of the Nebraska Academy of Sciences and Affiliated Societies by an authorized administrator of DigitalCommons@University of Nebraska - Lincoln. 


\title{
Importance of woodland patches as hibernacula for gartersnakes in a prairie river floodplain of central Nebraska
}

\author{
Anthony E. Bridger and Keith Geluso \\ Department of Biology, University of Nebraska at Kearney, Kearney, NE 68849 \\ Corresponding author: Keith Geluso; 308-865-8982; email gelusok1@unk.edu
}

\begin{abstract}
Gartersnakes are common inhabitants along prairie rivers in the Great Plains, but little information is known about hibernacula among diverse floodplain habitats. We radio-tracked Common Gartersnakes (Thamnophis sirtalis) and Plains Gartersnakes (Thamnophis radix) to hibernacula on islands in a braided river system subject to frequent environmental changes along the Platte River in central Nebraska. We further examined capture rates of gartersnakes in floodplain woodland patches from June to November to examine seasonal use of this habitat. In early and mid-September, movements of snakes with transmitters were in grasslands. From late September to mid-October, the farthest movements were documented, and snakes moved from grasslands into woodland patches. From late October to January, movements were minimal in and around hibernacula in wooded or formerly wooded habitats. Capture rates of gartersnakes in woodland trapping arrays also increased in October and November, further demonstrating woodland use during times when snakes travel to and reside at hibernacula. Although grasslands comprised most of the prairie islands at the study area, observations suggested that the limited woodlands on these islands are important for gartersnakes prior to and during hibernation along the Platte River in central Nebraska. Areas with large trees, such as Plains Cottonwoods (Populus deltoides), appeared to provide overwintering sites. In central Nebraska, riparian woodlands continue to be cleared to enhance habitat for endangered and threatened species such as Whooping Cranes (Grus americana), but some of these islands originally contained trees prior to European settlement. Conservation of at least some woodland habitats appears important for overwintering gartersnakes in central Nebraska.
\end{abstract}

Keywords: Common Gartersnake, floodplain, hibernacula, Nebraska, Plains Gartersnake, Platte River, Thamnophis radix, Thamnophis sirtalis, tree clearing, woodlands

DOI: $10.32873 /$ unl.dc.tnas.41.7

\section{Introduction}

Snakes in northern temperate climates typically hibernate during winter in response to seasonal low temperatures. Characteristics of hibernacula affect survival, and for snakes, underground hibernacula enable individuals to avoid predators, freezing temperatures, and dehydration (Gregory 1982, Rossman et al. 1996). Snakes commonly hibernate in burrows of other animals, crevices of rocks, hollow trees, rotting root systems, and south-facing slopes (Gregory 1982, Burger et al. 1988, Prior and Weatherhead 1996, Harvey and Weatherhead 2006). For some species, individuals employ freeze-avoidance or freeze-tolerance strategies to survive cold temperatures (Storey 2006). Only a few species can endure a few hours with temperatures as low as $-2.5^{\circ} \mathrm{C}$ (Churchill and Storey 1992). Multiple features likely are important for selection of hibernacula. Both temperature and relative humidity are important factors for determining survival rates in hibernating gartersnakes, with the coldest and most humid (i.e., saturated) environments resulting in the greatest survival rates (Costanzo 1989). Gregory (1982) stated that dormancy in reptiles is one of the most conspicuous aspects of their biology, with many approaches employed by these organisms to survive this seasonal aspect of their life history.

In the Great Plains, little is understood about how snakes use diverse floodplain habitats during autumn and winter. In central Nebraska, the Platte River historically was a broad braided river, but river channels have been encroached by trees in recent decades, in part, due to reduced flows associated with upstream dams and diversions (Johnson 1994). Remaining grasslands along the central Platte River primarily are grazed by 
domestic livestock and likely were not converted to agricultural lands due to historically high water tables and seasonal flooding (Nagel 1981). Today, woodlands occur along edges of river channels and on islands. During the last three decades, many riparian woodlands have been cleared along the Big Bend reach of the Platte River to enhance habitat for rare migratory birds, such as Whooping Cranes (Grus americana), Piping Plovers (Charadrius melo$d u s$ ), and Interior Least Terns (Sterna antillarum athalassos; National Research Council 2005). However, river islands along the Big Bend reach of the river near Grand Island, Nebraska, historically were wooded (Johnson 1994, Johnson and Boettcher 2000a), but controversy exists about the abundance of trees on islands prior to Europeans settling the Great Plains (Currier and Davis 2000, Johnson and Boettcher 2000a,b).

Common Gartersnakes (Thamnophis sirtalis) and Plains Gartersnakes (Thamnophis radix) are common grassland inhabitants of rivers and waterways in Nebraska (Ballinger et al. 2010, Fogell 2010, Geluso and Harner 2013b). Along the Platte River in central Nebraska, it was unknown whether these species hibernate in floodplains or move to surrounding uplands for winter. If snakes remain in floodplains, it also was unknown whether individuals hibernate in grassland or woodland habitats. For this project, we tracked movements of gartersnakes, determined distances travelled in late summer and autumn, described the habitat surrounding hibernacula, monitored seasonal activity of snakes in wooded riparian habitats, and determined body temperatures of snakes from autumn to early winter.

\section{Materials and Methods}

We conducted this study on the western portion of Mormon Island and eastern portion of Shoemaker Island in the floodplain of the Platte River on lands owned by The Crane Trust, Hall County, Nebraska, USA (Figure 1). Almost all grasslands on islands were maintained by a 4-year rotational strategy of burning, grazing, and resting in 2011 and by patch-burn grazing in 2013. Relatively few trees and wooded habitats existed on islands in our study area (Figure 1). During the 2011 field season, we captured gartersnakes in grasslands on Mormon Island by placing several $10-\mathrm{m}$, linear drift fences (i.e., woven polypropylene silt fences) with a single funnel trap (Gee's ${ }^{\circledR}$ Galvanized Minnow Traps, Model G-40, Tackle Factory, Fillmore, NY, USA) at each end of the fence. Dominant vegetation included native grasses such as Big Bluestem (Andropogon gerardii), Prairie Cordgrass (Spartina pectinata), and Indian Grass (Sorghastrum nutans); a diversity of prairie forbs; and nonnative Smooth Brome (Bromus inermis), Kentucky Bluegrass (Poa pratensis), and Redtop (Agrostis stolonifera).

To determine seasonal use of woodland patches and to capture snakes in grasslands for implanting transmitters during the 2013 field season (June 2013 to November 2013), we used 10-m diameter Y-shaped drift fences similar to those described above with a single funnel trap at each of the three ends on both Mormon and Shoemaker islands. In addition, each drift fence had one wooden cover-object $\left(\sim 0.5 \mathrm{~m}^{2}\right)$, one metal cover-object $\left(\sim 0.5 \mathrm{~m}^{2}\right)$, and two sheets of tar paper $\left(0.5 \mathrm{~m}^{2}\right.$ and $\left.2.0 \mathrm{~m}^{2}\right)$ placed adjacent to silt fences with one material type on each of the three sides. The center area of the drift fence was closed at the center. Hereafter, we called each combination of a Y-shaped fence, three funnel traps, and three types of cover-objects, an array. We constructed eight total arrays consisting of four pairs. Three pairs of arrays were located on Shoemaker Island and one pair of arrays was on Mormon Island. Each pair consisted of an array in a wooded area with a dense canopy and an array in an adjacent grassy area, some with scattered trees and open canopy. The tree community for densely wooded arrays consisted of mostly Eastern Red Cedars (Juniperus virginiana) and Plains Cottonwoods (Populus deltoides). Dense canopy arrays had little, if any groundcover. Scattered Plains Cottonwoods were located in some adjacent grassy arrays, with Big Bluestem (Andropogon gerardii) and Kentucky Bluegrass (Poa pratensis) as the primary ground cover. Each month from June 2013 to October 2013, we trapped ten consecutive days. In November 2013 , we only trapped for four consecutive days due to weather constraints.

\section{Implantation and Radio-tracking}

We inserted small, temperature-sensitive transmitters (BD-2T (1.8 g) or PD-2T (2.5 g); Holohil Systems Ltd., Ontario, Canada) in gartersnakes. We first anesthetized snakes with Brevital Sodium (Methohexital sodium, MWI Veterinary Supply, Boise ID, USA; Preston et al. 2010) by injecting subcutaneously a $0.5 \%$ solution at a dose of 0.3 $\mathrm{ml}$ per $100 \mathrm{~g}$ of body mass. The entire body of snakes was then sterilized by wiping with $70 \%$ ethanol. A $1.5-\mathrm{cm}$ incision was made through the skin and underlying muscles $3 / 4$ the distance of the snout-vent length posterior to the snake's head on the right side between the first and second row of scales dorsal to the ventral scales (Reinert and Cundall 1982). We inserted a transmitter into the coelomic cavity posterior to the incision, with each transmitter weighing $<5 \%$ of the snake's total body mass. We inserted the antenna anterior to the incision beneath the skin along 


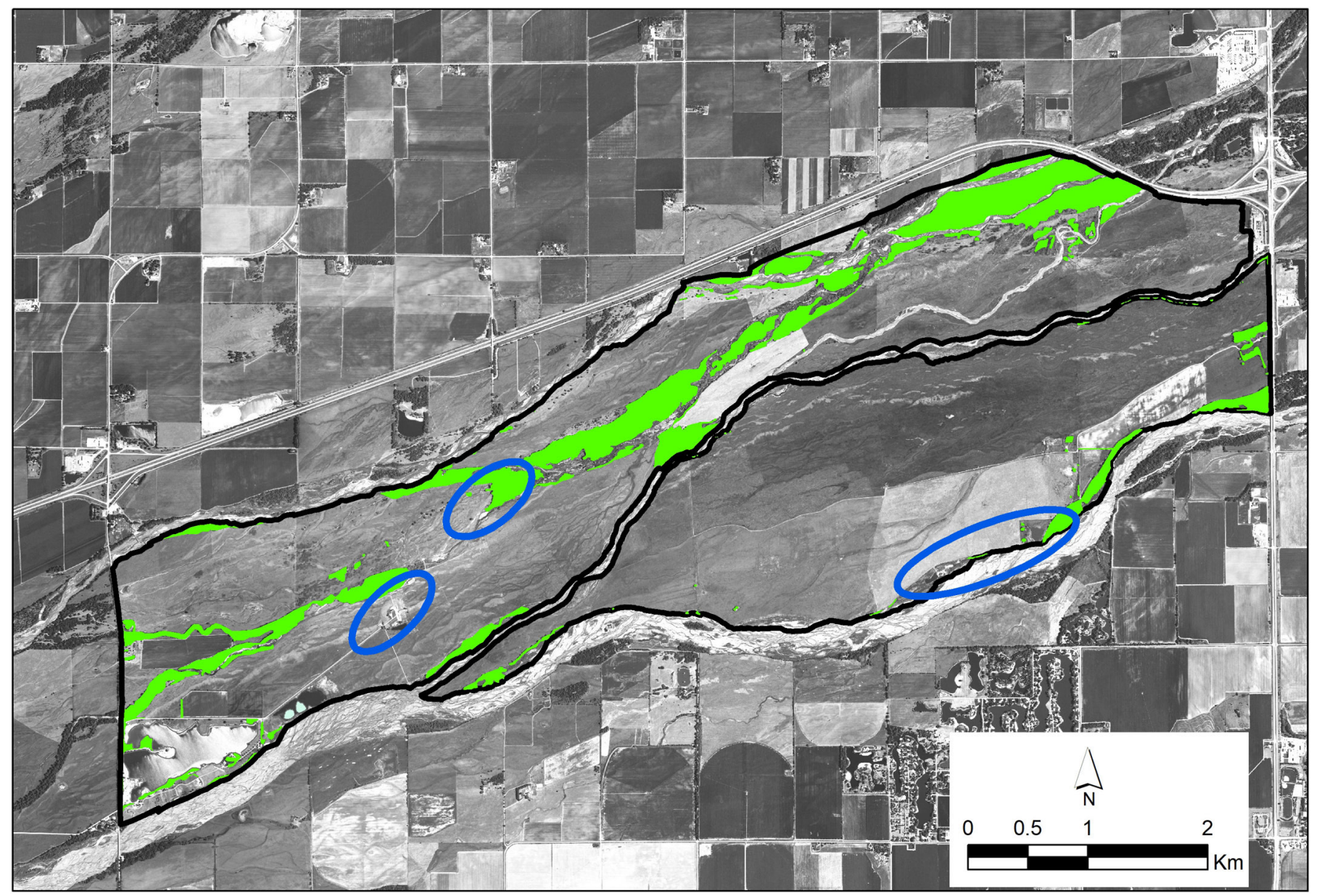

Figure 1. Aerial view of the western portion of Mormon Island (southeastern area outlined in black) and eastern part of Shoemaker Island (northwestern area outlined in black), Hall County, Nebraska, west of US Highway 281. Islands outlined in black were mainly owned by The Crane Trust. Highlighted green areas represented trees or woodlands on islands. Habitats on these two areas combined in 2011 consisted of $81.5 \%$ grassland, $11.8 \%$ woodlands, $4.7 \%$ agricultural lands, and $2.0 \%$ ponds. The blue ovals represent the study areas where gartersnakes were captured and tracked in the study.

the lateral line between scale rows two and three dorsal to the ventral scales (Reinert and Cundall 1982). We closed the incision with sutures (size 4-0, Polyglycolic Acid, Absorbable Braided Sutures; Oasis Medical, Mettawa, IL, USA) and sealed it with LiquiVet Rapid Tissue Adhesive (Oasis Medical, Mettawa, IL, USA). Snakes were held in captivity and monitored for at least three days to verify normal movements and no sign of infection before each was released at its capture site.

In 2011, we tracked individuals three to six times per week mostly during late afternoon or evening hours from September 2011 to January 2012 (R-1000 Receiver, Communication Specialists Inc., Orange, CA, USA; antennas, Wildlife Materials International, Inc., Murphysboro, IL, USA). In 2013, we tracked individuals three to six times per week, mostly during the morning or afternoon from September to mid-November. Additionally, we tracked snakes one last time on 19 January 2014 during a warm period.

For all locations of snakes, we recorded time of day and habitat (i.e., grassland or woodland). Coordinates of localities (i.e., latitude and longitude) were recorded with a handheld Global Positioning System (eTrex, Garmin International, Olathe, Kansas) using North American Datum 1983. We also recorded weather conditions and air temperatures around the time of observations from Weather Underground (wunderground.com; APRSWXNET station near Grand Island, Nebraska, 2011; Wood River Diversion USGS station near Grand Island, Nebraska, 2013). We also recorded some descriptive data for some snakes regarding observations at or around hibernacula. During 2011, we determined internal 
Table 1. Details for gartersnakes (Thamnophis) implanted with radio-transmitters in the floodplain of the Platte River in central Nebraska, 2011 (Snakes 1 - 4) and 2013 (Snakes 5 - 10). Lengths represent total length of snakes, and days tracked represents number of GPS fixes acquired during the study, which was mainly one per day.

\begin{tabular}{|c|c|c|c|c|c|c|c|c|c|c|c|}
\hline $\begin{array}{l}\text { Snake } \\
\#\end{array}$ & Species & Sex & $\begin{array}{l}\text { Length } \\
(\mathrm{cm})\end{array}$ & $\begin{array}{l}\text { Weight } \\
\text { (g) }\end{array}$ & $\begin{array}{l}\text { Initial } \\
\text { habitat }\end{array}$ & $\begin{array}{l}\text { Release } \\
\text { date }\end{array}$ & $\begin{array}{l}\text { Last } \\
\text { movement }\end{array}$ & $\begin{array}{l}\text { Final } \\
\text { habitat }\end{array}$ & $\begin{array}{l}\text { Signal } \\
\text { last heard }\end{array}$ & $\begin{array}{l}\text { Days } \\
\text { tracked }\end{array}$ & $\begin{array}{l}\text { Final } \\
\text { observation }\end{array}$ \\
\hline 1 & T. radix & $\mathrm{F}$ & 60 & 54 & Grassland & 7 Sep & 10 Sep & $\mathrm{N} / \mathrm{A}$ & 10 Sep & 3 & Signal lost \\
\hline 3 & T. sirtalis & M & 64 & 65 & Grassland & 7 Sep & $20 \mathrm{Nov}$ & Woodland & $20 \mathrm{Nov}$ & 60 & $\begin{array}{l}\text { Predated but previously } \\
\text { hibernating }\end{array}$ \\
\hline 4 & T. sirtalis & $\mathrm{F}$ & 107 & 186 & $\begin{array}{l}\text { Grassland } \\
\text { w/scattered } \\
\text { trees }\end{array}$ & 25 Sep & $6 \mathrm{Nov}$ & $\begin{array}{l}\text { Concrete blocks } \\
\text { \& a few trees }\end{array}$ & 13 Jan & 53 & Hibernating \\
\hline 5 & T. sirtalis & $\mathrm{F}$ & 86 & 105 & Grassland & 11 Sep & $15 \mathrm{Nov}$ & Woodland & 19 Jan & 25 & $\begin{array}{l}\text { Predated but previously } \\
\text { hibernating }\end{array}$ \\
\hline 6 & T. sirtalis & $\mathrm{F}$ & 74 & 97 & Grassland & 3 Oct & 22 Oct & $\mathrm{N} / \mathrm{A}$ & $\mathrm{N} / \mathrm{A}$ & 7 & $\begin{array}{l}\text { Moved off property } \\
\text { after } 22 \text { Oct }\end{array}$ \\
\hline 7 & T. sirtalis & $\mathrm{F}$ & 84 & 95 & Grassland & 13 Oct & $19 \mathrm{Nov}$ & $\begin{array}{l}\text { Area w/large } \\
\text { trees removed }\end{array}$ & $19 \mathrm{Nov}$ & 11 & Hibernating \\
\hline 10 & T. radix & $\mathrm{F}$ & 73 & 82 & Grassland & 30 Oct & $7 \mathrm{Nov}$ & Woodland & $7 \mathrm{Nov}$ & 2 & Predated \\
\hline
\end{tabular}

temperatures of snakes by monitoring the time interval between signals from transmitters. Temperature-dependent curves were supplied with transmitters, and we verified each curve before implantation of transmitters into snakes. In March 2012, we excavated one snake (Snake 2) from its hibernaculum to learn more about the underground microhabitat of the site.

\section{Results}

In September 2011, we radio-tracked four gartersnakes: two T. sirtalis and two T. radix (Table 1). In 2013, we radio-tracked six gartersnakes: five T. sirtalis and one T. radix (Table 1). In 2013, we attempted to implant all snakes in September but had difficulties capturing most individuals until mid- to late October, thus we separated movement data by year. In 2011, we did not detect a transmitter signal for Snake 1 after the third day (Table 1), and it was unclear whether the transmitter failed or the snake moved a distance beyond our abilities to detect it. We do not present any further data on this individual hereafter.

In 2011, distances traveled and habitats used by radio-tracked snakes differed as the season progressed toward winter. In September, most gartersnake movements were in grasslands near sites of capture (Figures 2 and 3). From late September through October, gartersnakes travelled their greatest distances towards hibernacula in woodlands (Figures 2-4, Table 2). Snake 2 travelled its three greatest distances 2-6 October, with the longest, 663 $\mathrm{m}$, on 4 October (Figure 2). Snake 3 travelled $395 \mathrm{~m}$ on 21 October and $443 \mathrm{~m}$ on 22 October (Figure 3). Snake 4 travelled its greatest distance, $647 \mathrm{~m}$, on 26 September and then $180 \mathrm{~m}$ on 27 September (Figure 4). From November to January, movements, if any, were minimal, and snakes hibernated in wooded areas or an area with concrete blocks and a few small trees.

In October and early November 2013, gartersnakes made their greatest movements towards hibernacula, mainly to wooded habitats (Figures 5-10, Table 2). The greatest distance moved by snakes included $425 \mathrm{~m}$ on 7 November (Snake 5), $415 \mathrm{~m}$ on 12 October (Snake 6), 92 $\mathrm{m}$ on 17 October (Snake 7), $74 \mathrm{~m}$ on 22 October (Snake 8), and $256 \mathrm{~m}$ on 20 October (Snake 9). From November to January 2013, similar to 2011, movements again were minimal, and snakes hibernated in wooded areas or an area where trees had been cleared based on historical photographs and satellite images.

During the two years of this project, all nine snakes tracked late in the season either hibernated in or moved through wooded patches, scattered trees, or former patches of trees on islands (Table 1, Figures 2-10). We originally captured eight of nine gartersnakes in areas dominated by grasslands (Table 1). In 2011, distances from capture sites to hibernacula were $1.2 \mathrm{~km}, 1.1 \mathrm{~km}$, and $0.1 \mathrm{~km}$ (Snakes 2, 3, and 4; respectively). From November 2011 to January 2012, snakes only were documented at 


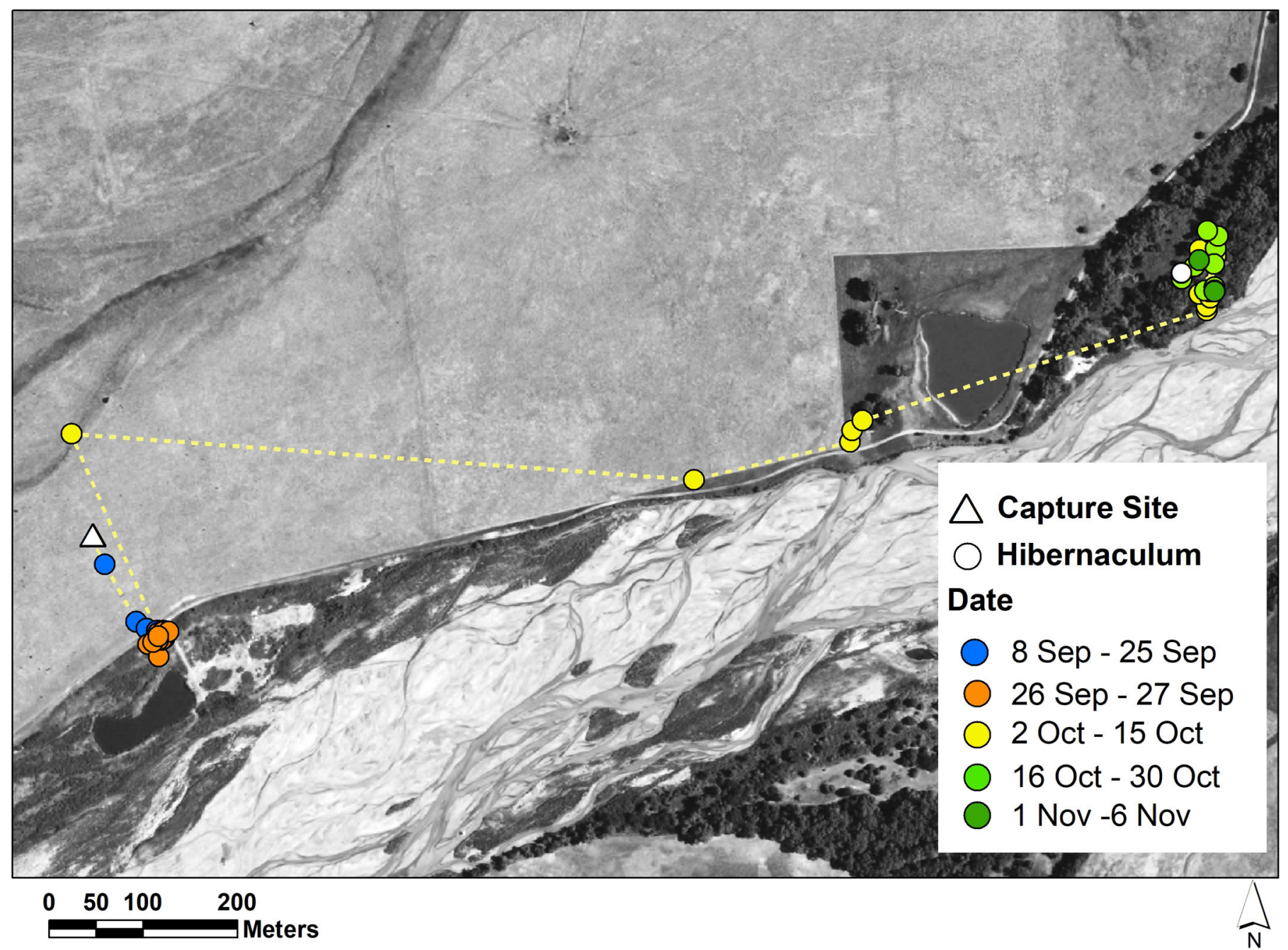

Figure 2. Locations of a female Plains Gartersnake (Thamnophis radix; Snake 2) implanted with a radio-transmitter in the floodplain of the Platte River from 7 September 2011 to 13 January 2012. All locations after 6 November were at the hibernaculum (white circle). The individual originally was captured in grasslands (white triangle), but the snake hibernated in a woodland patch on Mormon Island. The straight-line distance between the capture site and hibernaculum was $1.2 \mathrm{~km}$.

Table 2. Mean and maximum distances $(\mathrm{m})$ between observations of gartersnakes (Thamnophis radix and Thamnophis sirtalis) acquired with radio-telemetry in the floodplain of the Platte River, Nebraska, September 2011-January 2012 and September 2013-January 2014. On occasion individuals were tracked twice on the same day. Total number of observations is given as $n$ for the month.

\begin{tabular}{llll} 
& Mean & Maximum & $n$ \\
\hline September & 45.3 & 646.7 & 58 \\
October & 53.4 & 663.0 & 116 \\
November & 24.1 & 424.9 & 59 \\
December & 0.0 & 0.0 & 10 \\
January & 0.0 & 0.0 & 8 \\
\hline
\end{tabular}




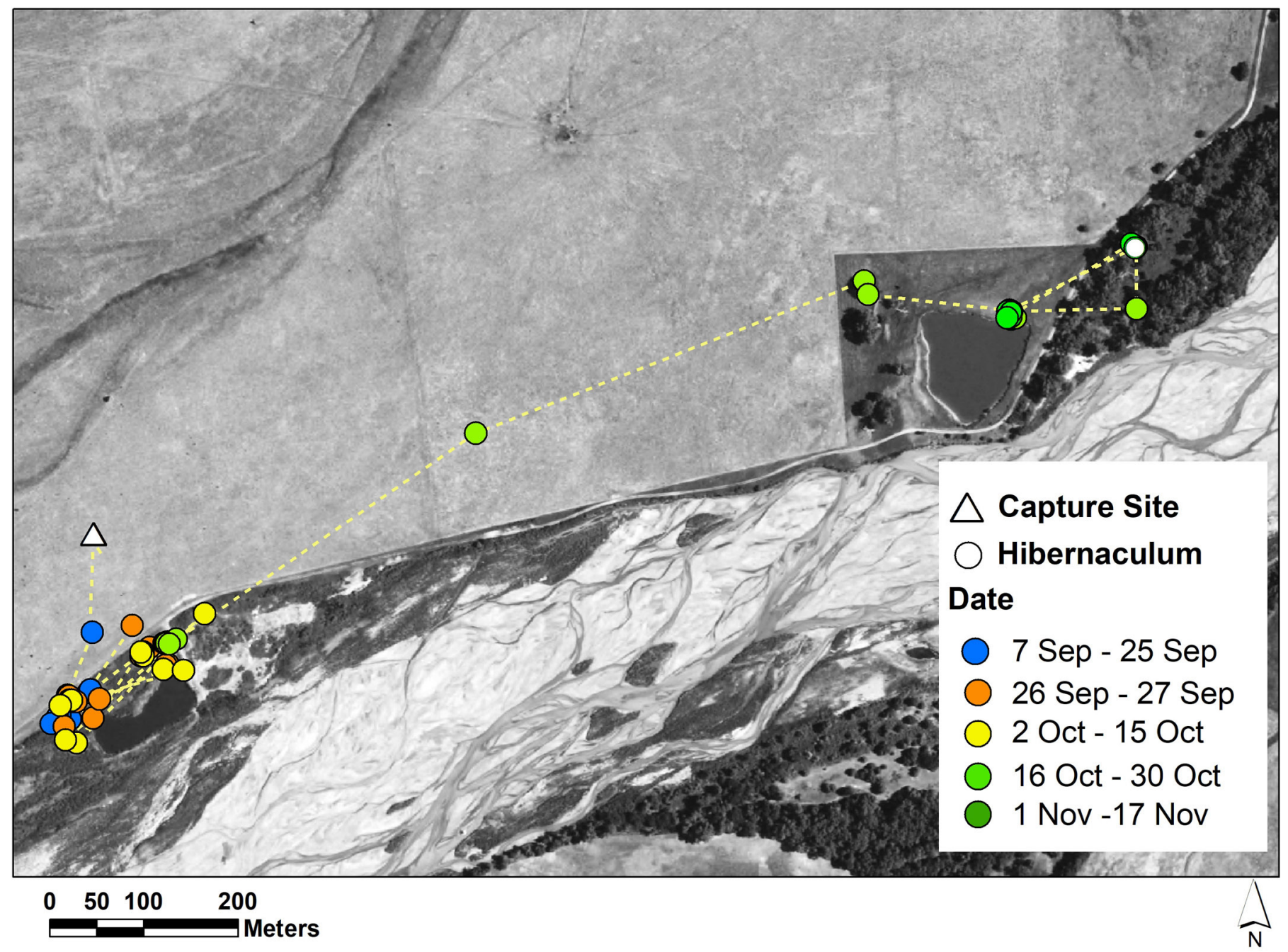

Figure 3. Locations of a male Common Gartersnake (Thamnophis sirtalis; Snake 3) implanted with a radio-transmitter in the floodplain of the Platte River from 7 September to 20 November 2011. The individual was associated with a large, dead Plains Cottonwood (Populus deltoides) for a hibernaculum (white circle) in November on colder days before the individual was detected predated on 20 November. The individual originally was captured in grassland habitats (white triangle), but the snake hibernated in a small woodland on Mormon Island. The straight-line distance between the capture site and hibernaculum was $1.1 \mathrm{~km}$.

hibernacula (Figures 2, 3, and 4). In 2013, distances from capture sites to hibernacula were $0.4 \mathrm{~km}, 0.2 \mathrm{~km}, 0.1 \mathrm{~km}$, and $0.3 \mathrm{~km}$ (Snakes 5, 7, 8, and 9; respectively), though these snakes were captured later in the season and closer to wooded areas. Overall, we tracked seven gartersnakes to hibernacula (Table 1).

\section{Details of Radio-tracked Snakes in 2011}

Snake 2 entered its hibernaculum on 6 November on a north-facing slope of a small rise in a woodland $30 \mathrm{~m}$ from an active river channel. On 14 March 2012, we excavated this snake (T. radix). It was located $11.5 \mathrm{~cm}$ below the ground surface in sandy soil covered with deciduous leaves. Vines and small shrubs were $<2 \mathrm{~m}$ from the site, and a large cottonwood was about $4 \mathrm{~m}$ away. Dominant tree species included Plains Cottonwoods, Green Ash (Fraxinus pennsylvanica), and Common Hackberry (Celtis occidentalis). Almost no Eastern Red Cedars were present in the woodland. A narrow underground chamber existed that extended downward beyond the snake's location for at least $8 \mathrm{~cm}$, and it is unclear what made the cavity.

Snake 3 commonly was associated with the base of a large, dead Plains Cottonwood in late October and 


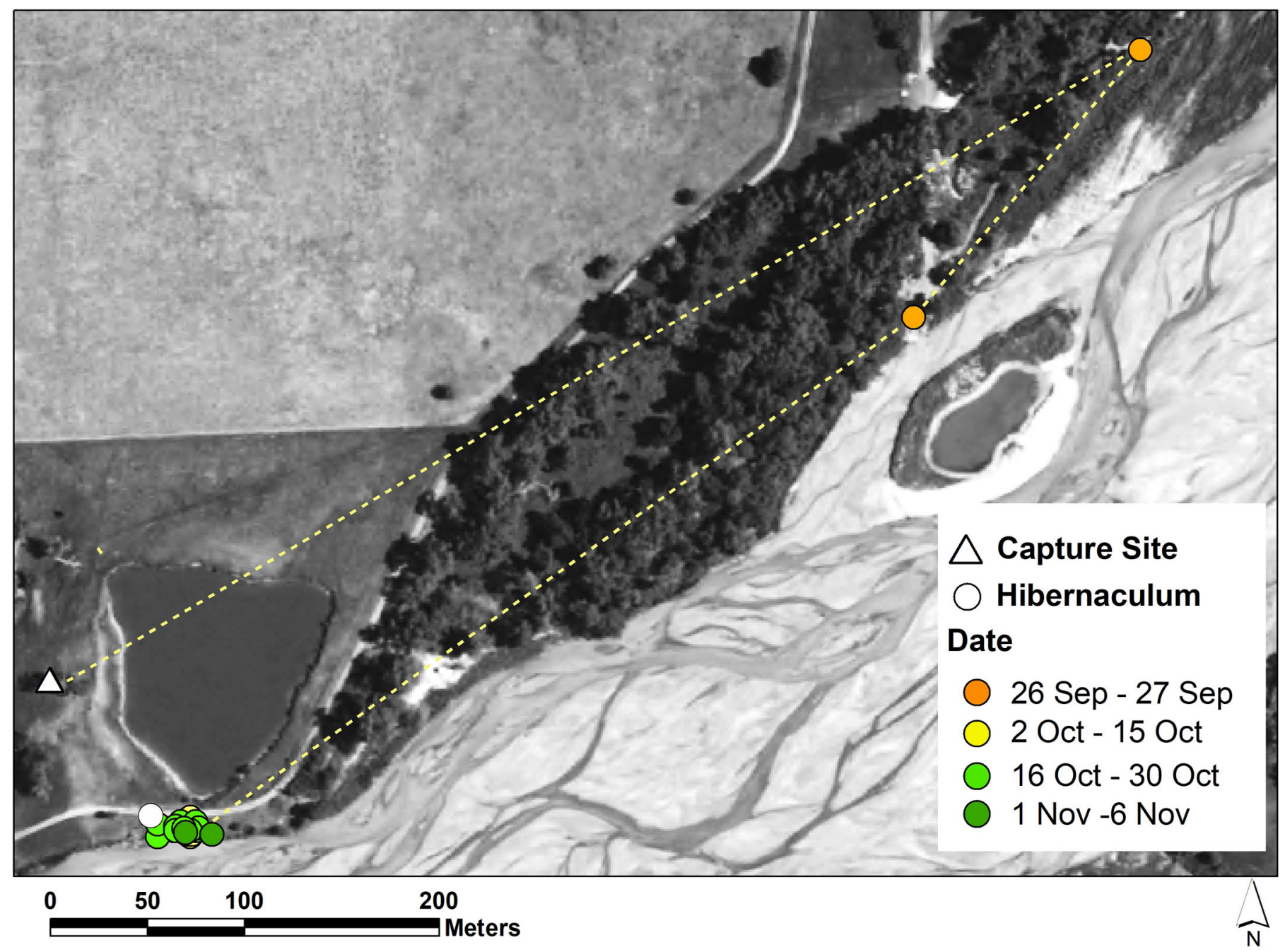

Figure 4. Locations of a female Common Gartersnake (Thamnophis sirtalis; Snake 4) implanted with a radio-transmitter in the floodplain of the Platte River from 25 September 2011 to 13 January 2012. All locations after 6 November were at the hibernaculum (white circle). The individual originally was captured in a grassy area with scattered large trees (white triangle), but the snake hibernated in stabilizing concrete blocks along the bank of an active channel of the Platte River with a few smaller trees in the immediate area. The straight-line distance between the capture site and hibernaculum was $0.2 \mathrm{~km}$.

November on cold days, but on warm days, the snake was located in nearby grassland habitats near a pond (Figure 3 ). We did not observe the snake above ground, but the base of the tree and the top of a large exposed root had holes suggesting it was hollow. The cottonwood tree was along the ecotone between the grassland and woodland. This individual was found dead and partially eaten on 20 November 2011 in the nearby grassland after a cold period.

Snake 4 hibernated along the edge of an active river channel beneath large pieces of concrete used to stabilize the riverbank (Table 1, Figure 4). This site had a south-facing exposure with small, scattered trees along the bank. Around the concrete, we observed numerous rodent holes and at least two unmarked T. sirtalis.

\section{Details of Radio-tracked Snakes in 2013}

Snake 5 moved to a densely wooded portion of Shoemaker Island. The area contained no Eastern Red Cedars and was dominated by Plains Cottonwoods (Figure 5). The snake subsequently was found dead and mostly eaten on 19 January 2014 during a warm period. Snake 6 moved onto private property north of the Crane Trust 


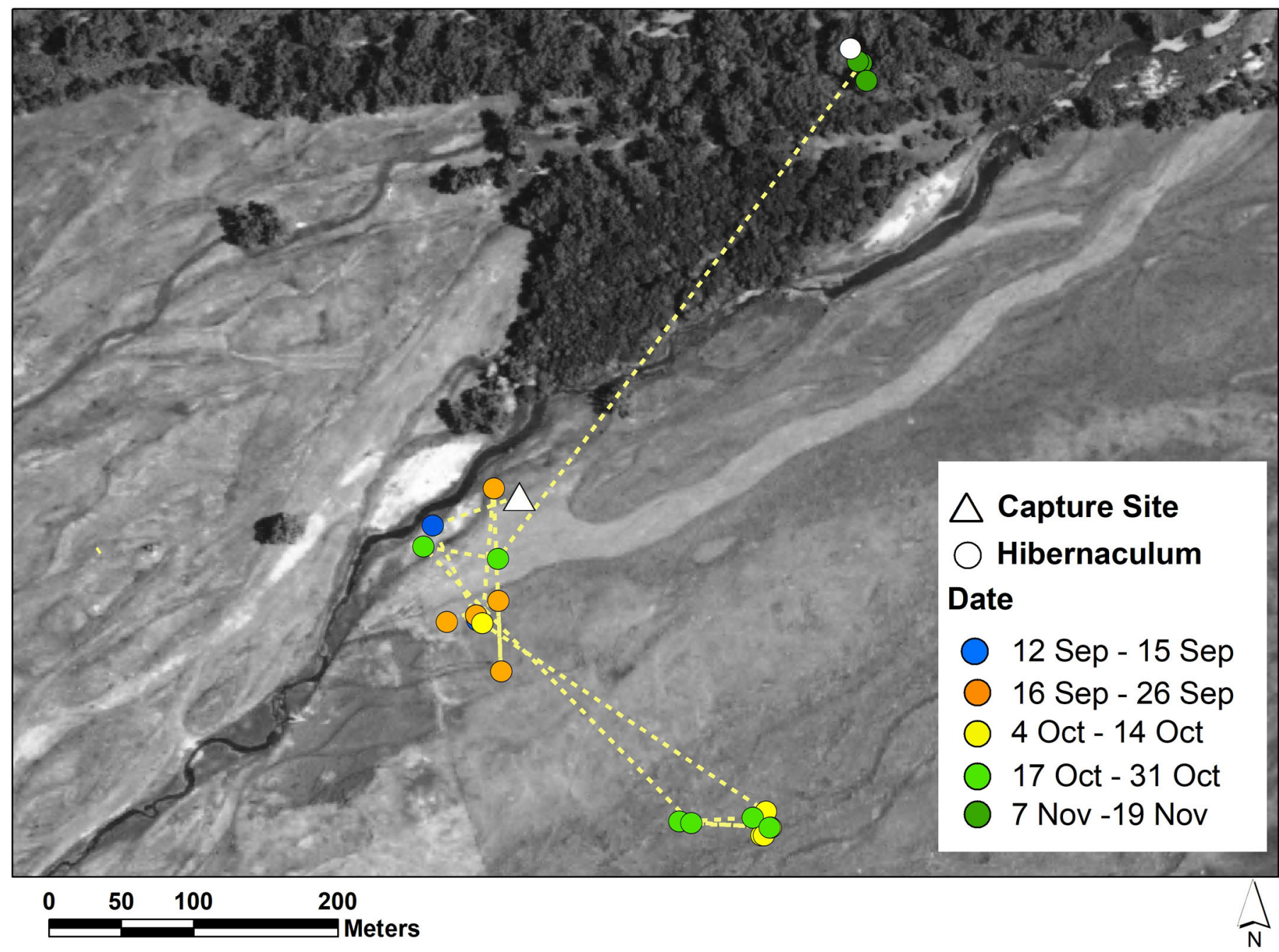

Figure 5. Locations of a female Common Gartersnake (Thamnophis sirtalis; Snake 5) implanted with a radio-transmitter in the floodplain of the Platte River from 11 September 2013 to 19 January 2014. All locations after 15 November were at the hibernaculum (white circle). The individual originally was captured in grasslands (white triangle), but it hibernated in a woodland patch. The straight-line distance between the capture site and hibernaculum was $0.4 \mathrm{~km}$. Individual was observed predated on 19 January 2014 during a warm period.

between the 22 and 25 October (Figure 6). This snake remained on private property and its exact location was never determined after 22 October 2013. Snake 7 moved to a previously wooded location with many tree stumps and downed logs (Figure 7). The location consisted of sandy soil near a human-made pond with grape vines and some willows still present. Snake 8 was captured in the woodland on Shoemaker Island and remained in the area throughout our observations (Figure 8). It hibernated below the base of a large Plains Cottonwood Tree in a woodland dominated by cottonwoods. Snake
9 was captured in the parking lot of the Crane Trust surrounded by grasslands and subsequently moved into a woodland for hibernation (Figure 9). The woodland was dominated by Eastern Red Cedars with sandy soil and little ground cover.

\section{Body Temperatures and Woodland Capture Rates}

In 2011, average body temperatures of snakes declined September-December, as did ambient temperatures at the time of observations (Figures 11 and 12). Variation 


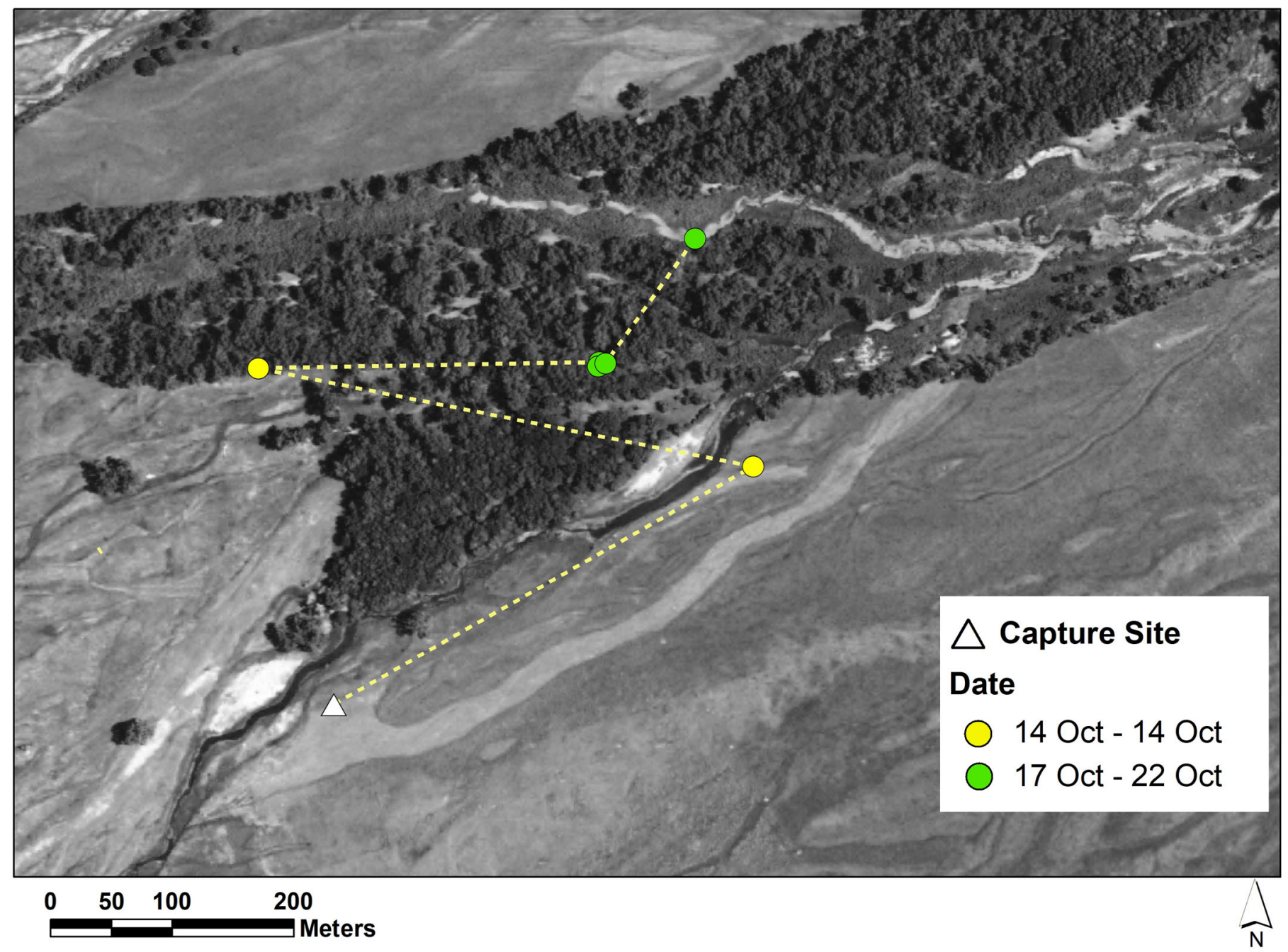

Figure 6. Locations of a female Common Gartersnake (Thamnophis sirtalis; Snake 6) implanted with a radio-transmitter in the floodplain of the Platte River from 3 October to 22 October 2013. The individual originally was captured in grasslands (white triangle) but moved through a wooded area before moving north of the property on 22 October. The final location for its hibernaculum was never determined due to land access constraints.

in body temperature of snakes was greatest in September and October and lowest in November and December (Figure 11). Average body temperatures were greater than ambient air temperatures at the time of observations (Figure 12).

Capture rates of gartersnakes in woodland arrays were monitored from June 2013 to November 2013. The lowest captures per trap night occurred in August 2013, whereas the highest captures occurred in November 2013 (Figure 13).

\section{Discussion}

Our study demonstrated that gartersnakes captured in grasslands during September and October in 2011 and 2013 generally were associated with wooded habitats during hibernation along the Platte River in central Nebraska. Gartersnakes on the western end of Mormon Island selected woodlands that only comprised 3\% of the island for hibernacula rather than adjacent grasslands that comprised $91 \%$ of the island floodplain (Figure 1). On 


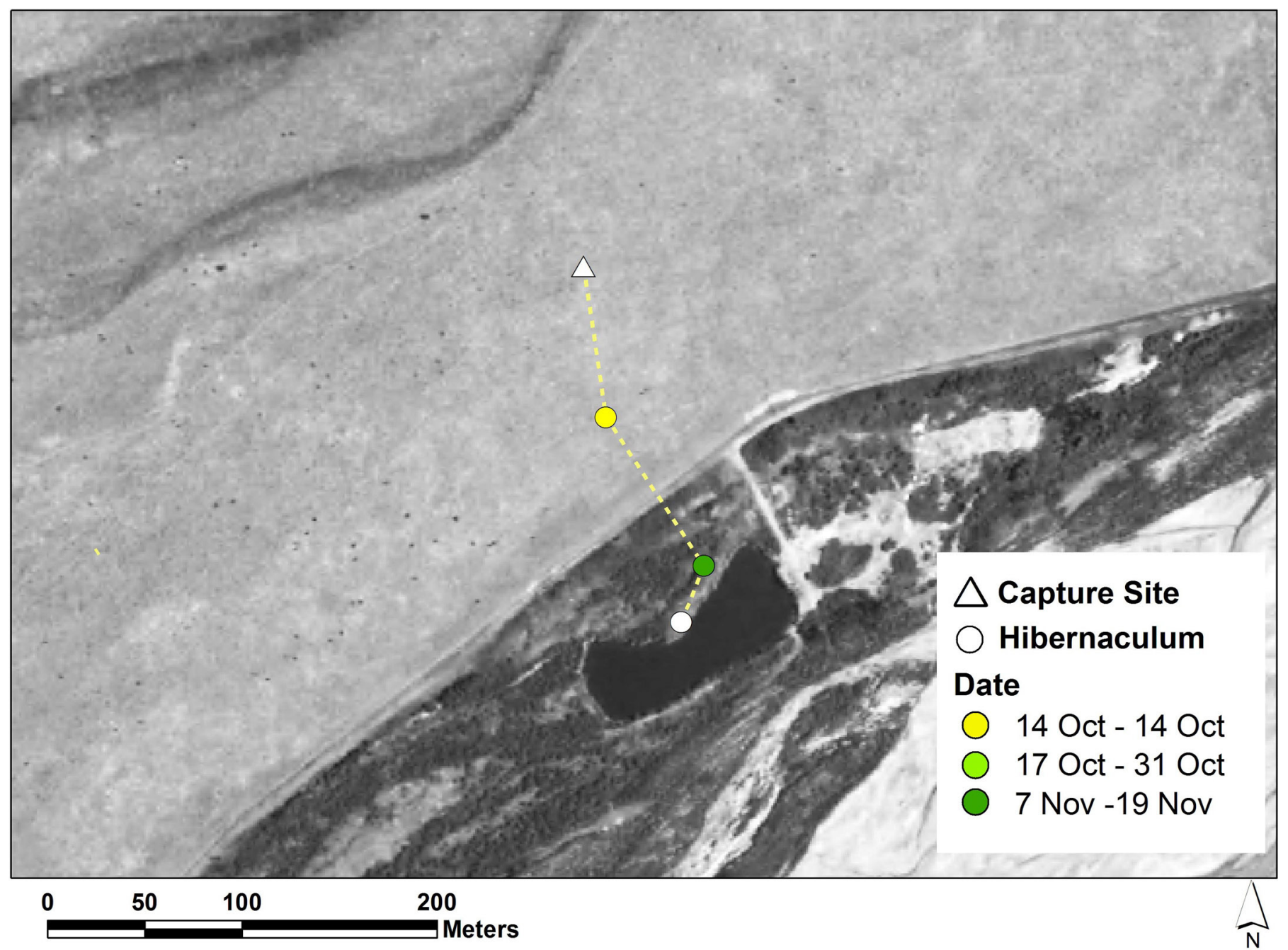

Figure 7. Locations of a female Common Gartersnake (Thamnophis sirtalis; Snake 7) implanted with a radio-transmitter in the floodplain of the Platte River from 13 October to 19 November 2013. All locations after the 19 November were at the hibernaculum (white circle). The individual originally was captured in grasslands (white triangle) and hibernated in disturbed portion of the island which was previously wooded and still contained many logs and stumps where trees were cut down. The straight-line distance between the capture site and hibernaculum was $0.2 \mathrm{~km}$.

Shoemaker Island, individuals resided in wooded habitats that comprised about $18 \%$ of the island with about $76 \%$ of the area dominated by grasslands (Figure 1). Capture rates of gartersnakes in woodlands also increased in October and November, further suggesting movements into such habitats for overwintering.

Hibernation is an adaptive strategy for reducing costs during a time of year when few benefits are available for reptiles (Gregory 1982). Long distances (>1 km) travelled by several snakes suggest such wintering sites are limited along the Platte River, as relative distances traveled between summer habitats and winter hibernacula likely relate to their availability and spatial arrangement (Gregory
1982). In 2013, we captured gartersnakes later in the season, many likely already moving towards wooded hibernacula, with a few originally captured in wooded habitats late in the season. Many snake species, including gartersnakes, are not known for digging their own hibernacula, and thus, rely on natural or human-made cavities that infiltrate depths that afford protection (Gregory 1982). We suspect large trees in wooded habitats, such as Plains Cottonwoods, provided snakes with aspects required for successful winter survival unavailable in surrounding grasslands.

Cottonwoods and other trees are common features of islands along the central Platte River today as well as 


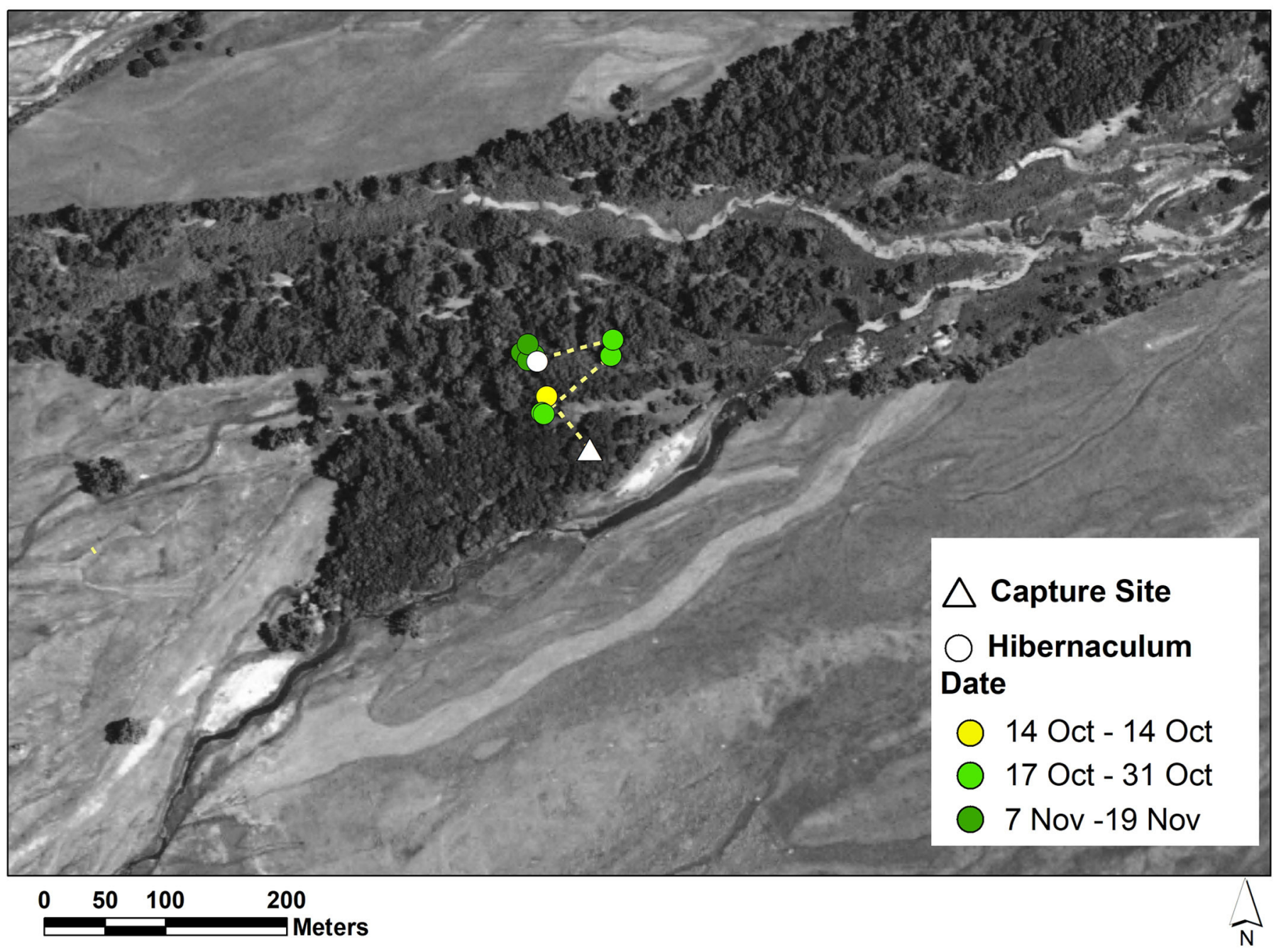

Figure 8. Locations of a female Common Gartersnake (Thamnophis sirtalis; Snake 8) implanted with a radio-transmitter in the floodplain of the Platte River from 13 October to 19 January 2014. All locations after the 19 November were at the hibernaculum (white circle). The individual originally was captured in woodland patch (white triangle) and hibernated nearby in the woodland. The straight-line distance between capture site and hibernaculum was $0.1 \mathrm{~km}$. This individual was captured later than other snakes and likely had already moved to the wooded area from grasslands, as traps were open throughout the season and the snake was not captured previously in the woodland.

before European settlement of the area in the mid-1800s (Johnson 1994, Johnson and Boettcher 2000a). For cottonwoods, root systems are a network of lateral and vertical roots, with some penetrating the water table several meters below ground surface (Pregitzer and Friend 1996). Hollow or decomposed roots likely provide a stable pathway by which snakes can deeply enter floodplain soils to seek protection from freezing temperatures and access moist or saturated soils. Studies have demonstrated snakes hibernate in old root systems of trees in other parts of North America (e.g., Harvey and Weatherhead 2006). Potential access to the water table or saturated soils also is important for some snake species (Carpenter 1953). Costanzo (1989) demonstrated that one species of gartersnake (T. sirtalis) experienced increased survival when submerged for at least part of the hibernation cycle at temperatures just above freezing.

The central Platte River is comprised of a sand-bed river lacking bedrock, thus deep, rocky fissures often used by other snake species are not present and available for hibernation on the local landscape. Whereas root systems of trees in wooded areas can afford deep access into the floodplain, grassland habitats likely do not provide such attributes along the Platte River in central Nebraska. 


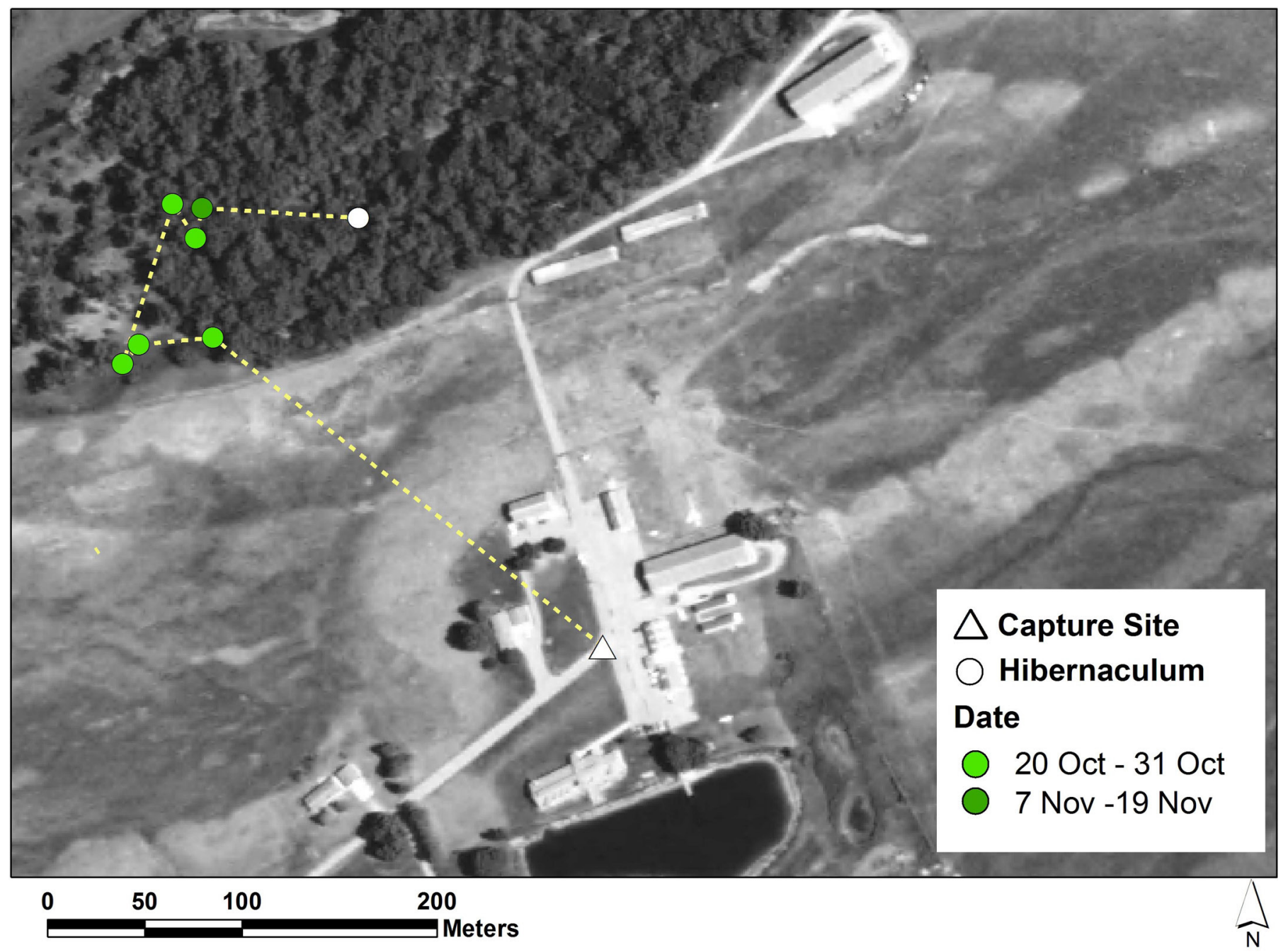

Figure 9. Locations of a female Common Gartersnake (Thamnophis sirtalis; Snake 9) implanted with a radio-transmitter in the floodplain of the Platte River from 19 October to 19 January 2014. All locations after the 19 November were at the hibernaculum (white circle). The individual originally was captured by hand in a parking lot surrounded by grasslands (white triangle) but hibernated in a nearby woodland patch. The straight-line distance between the capture site and hibernaculum was $0.3 \mathrm{~km}$.

Burrows created by animals might provide the only access into sandy soils in grasslands, but burrows that penetrate the water table appear limited along this reach of the river. Burrows of small mammals, such as Eastern Moles (Scalopus aquaticus) and Meadow Voles (Microtus pennsylvanicus), were abundant in grasslands. In September 2011, we often tracked gartersnakes into tunnels of Eastern Moles prior to their movements towards wooded hibernacula. However, those small mammals only provide temporary subterranean retreats generally above the water table. In other wetland ecosystems, crayfish create burrows into saturated soils that are commonly used as hibernacula by snakes, including gartersnakes in southeastern Nebraska (Patten 2006), but those retreats are usually in silty or clay soils (e.g., Carpenter 1953, Kingsbury and Coppola 2000). We did not observe crayfish burrows along sloughs, grasslands, or river channels on these islands. Thus, limited access to the water table for hibernacula might be a factor contributing to selection of woodlands for winter retreats of gartersnakes on the central Platte River. Sandy soils and lack of crevices in bedrock might be rather unique features of the central Platte River floodplain.

Mormon and Shoemaker Islands have relatively high water tables (Henszey et al. 2004). Low-lying areas on the northern half of Mormon Island form wet meadows 


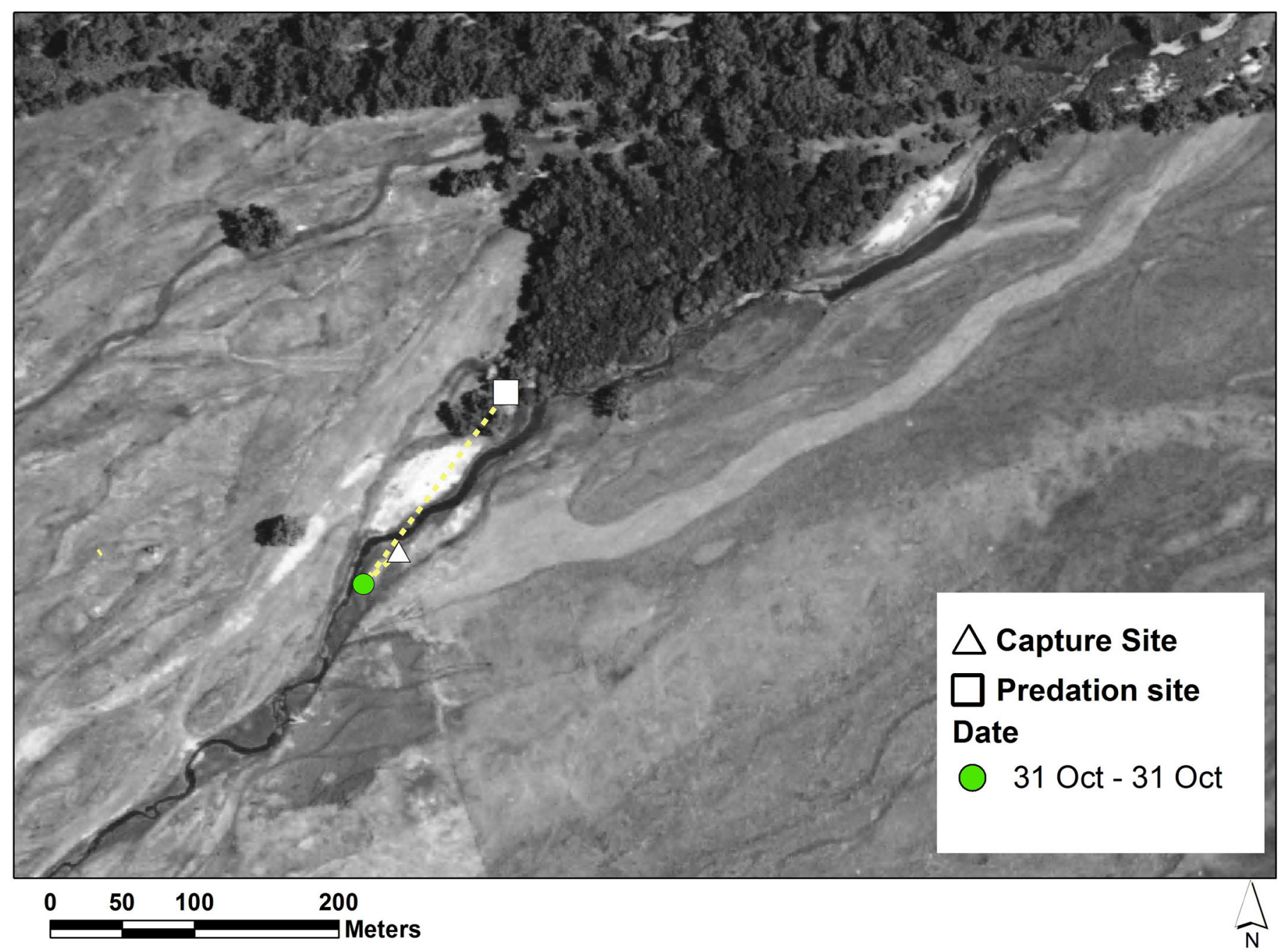

Figure 10. Locations of a female Plains Gartersnake (Thamnophis radix; Snake 10) implanted with a radio-transmitter in the floodplain of the Platte River from 30 October to 7 November 2013. The individual originally was captured in grasslands (white triangle), but the transmitter was discovered in a woodland patch on the island after apparent predation event on 7 November.

where ground water is at the surface. Other areas contain up to $\sim 2 \mathrm{~m}$ of soils above the water table, thus areas of the floodplain likely contain small-mammal burrows to adequate depths to prevent lethal temperatures for snakes, but only trees likely create access to depth below the water table. Although the high water table may benefit gartersnakes, an elevated water table is suspected to restrict the occurrence of Gophersnakes (Pituophis catenifer) and North American Racers (Coluber constrictor) on islands (Jones et al. 1981).

Understanding the role that trees and patches of woodlands play along the Platte River is vital because such wooded habitats have been cleared from along the
Big Bend reach of the river for endangered and threatened species for the past 30 years (National Research Council 2005). Specific benefits to Whooping Cranes, Piping Plovers, and Least Terns have yet to be documented as "Few data have been collected in vegetation removal projects that illuminate the effectiveness of clearing. Thus, exactly what is lost and gained through woodland removal is often poorly known" (National Research Council 2005). Our study suggests that wooded habitats are important for at least two species of native snakes during autumn and winter. Gartersnakes likely serve as a food resource for Whooping Cranes during migratory stopovers because these cranes are mainly carnivorous and consume snakes 


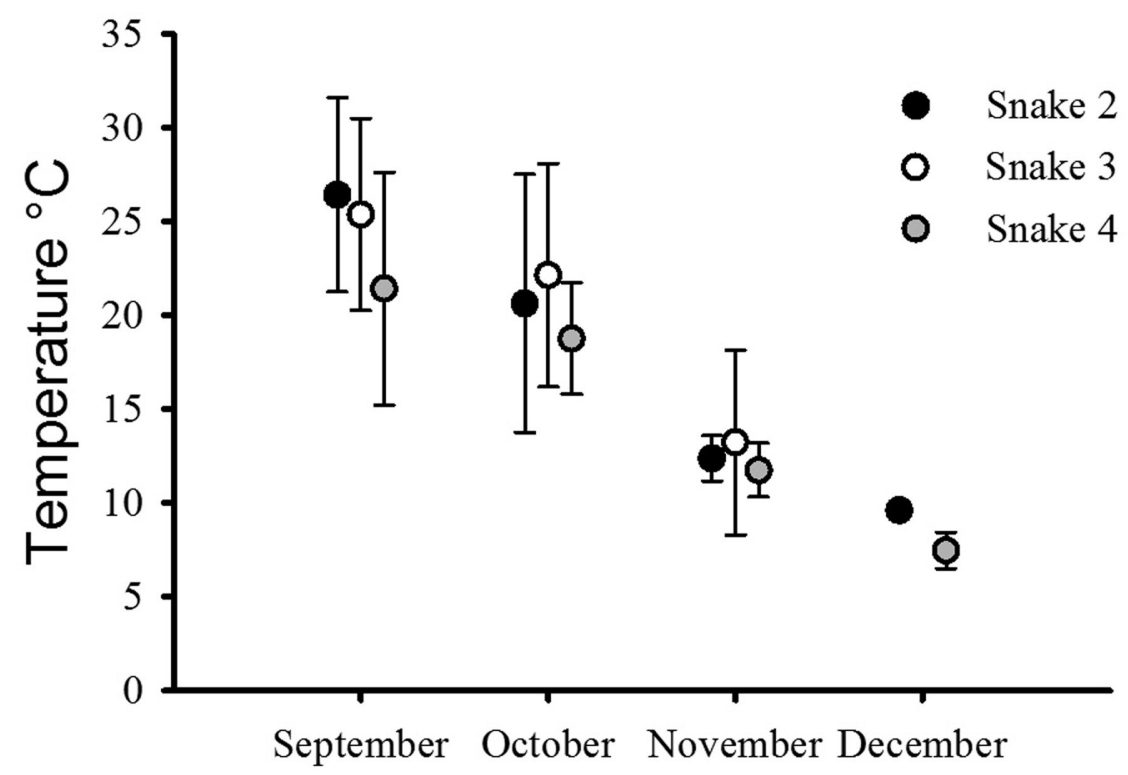

Figure 11. Monthly mean body temperatures $( \pm 1 S D)$ of three garter snakes (one Thamnophis radix, Snake 2 and two Thamnophis sirtalis, Snake 3 and 4) from a floodplain along the Platte River, Nebraska, 2011. We calculated body temperatures during daylight hours at the time of observation from pulses from radio transmitters (see Methods). In November, Snake 3 was observed above ground later into the month than the other two snakes but predated late in the month, thus not included in December temperature data. In December, snakes always were underground on the days of tracking, hence the low variation in body temperatures.

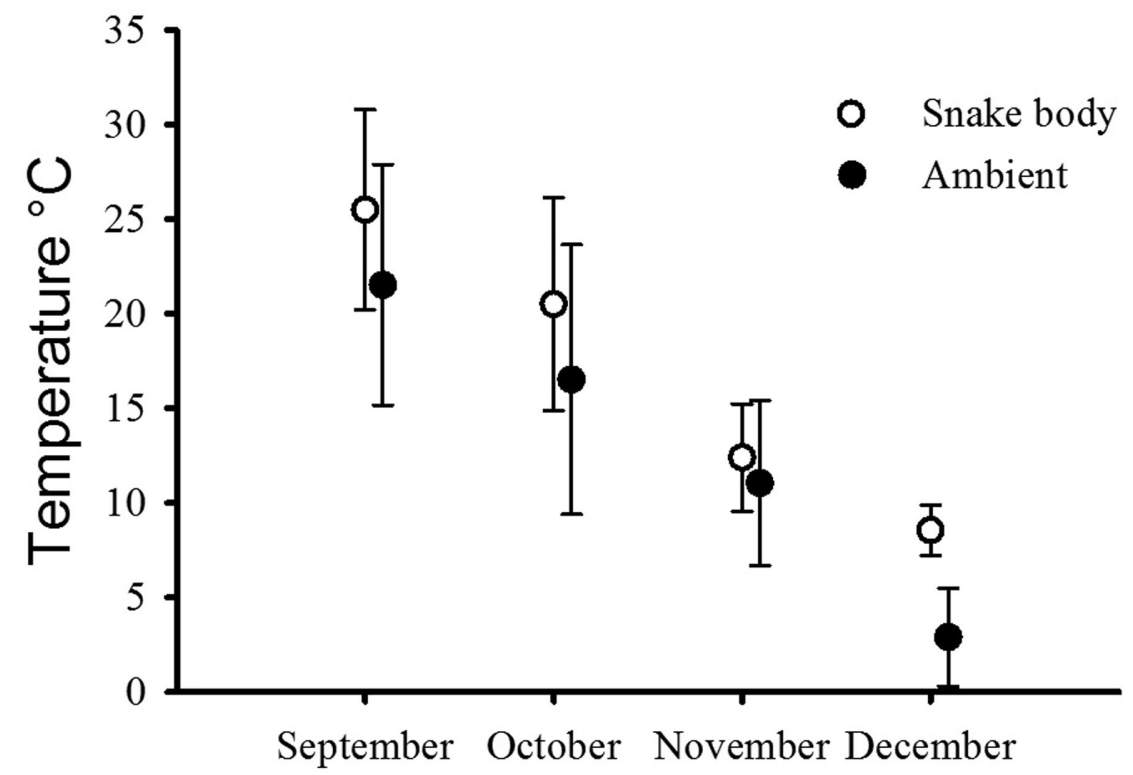

Figure 12. Monthly mean body temperature of three gartersnakes (1 Thamnophis radix and 2 Thamnophis sirtalis) and mean ambient air temperatures ( \pm 1 SD) at the time of observation in 2011. Temperatures were obtained during daylight hours, and ambient temperatures were acquired from Weather Underground (wunderground.com). In December, snakes always were underground on days of tracking, hence the low variation in body temperatures but higher body temperatures than ambient air temperatures. One snake (Snake 3) was predated in November and not included in December temperature data. 


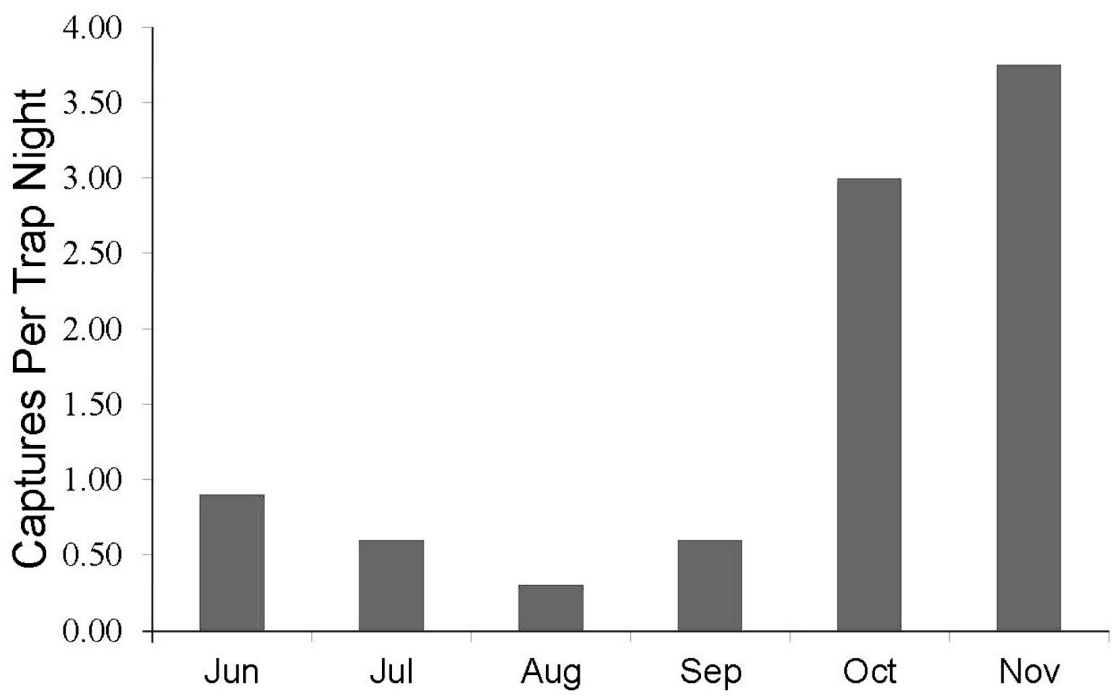

Figure 13. Number of gartersnakes captured per trap night in woodland trapping arrays in 2013. Trapping was conducted for 10 consecutive days each month except November when traps were opened only four days due to weather.

(Allen 1952, Austin and Richert 2001, Geluso and Harner 2013a). Further support for conservation of woodlands in the area is associated with the presence of an isolated population of Red-bellied Snakes (Storeria occipitomaculata; Ballinger et al. 2010, Fogell 2010), a state species of concern (Schneider et al. 2011). Red-bellied Snakes are a woodland species throughout other parts of its distribution (Fogell 2010). A recent herpetological survey on Mormon and Shoemaker islands documented this species only around some of the last remaining woodlands on the islands (Geluso and Harner 2013b), that is, some of the same woodland where gartersnakes overwintered. Moreover, those authors did not find the species in trapping arrays distant from patches of woodlands on either island (Geluso and Harner 2013b). Further research is needed to determine the specific features of woodlands, or the trees within woodlands, that afford gartersnakes (and Red-bellied Snakes) important habitats in autumn and winter. Tree clearing in and along the Platte River certainly benefits grassland birds and creates roosting sites for cranes, terns, and plovers, but at least some woodlands also are a natural and integral component of this river ecosystem. We propose that the oldest woodland patches of native trees be preserved, especially those with observations of Red-bellied Snakes. Sandhill Cranes (Antigone canadensis), and likely Whooping Cranes, also benefit from patches of woodlands along river channels as trees afford protection during inclement weather during migration (Aronson 1980).
River floodplains are diverse, complex systems created and maintained by floods, but degradation of floodplains can reduce biodiversity and ecological integrity (Naiman et al. 1993, Tockner and Stanford 2002). Floods expose new surfaces and reset ecological succession, but areas not scoured by recent floods can contain late-successional mature forests (Van Pelt et al. 2006, Whited et al. 2007, Harner et al. 2011). Although the Platte River is a regulated river, proximity of contrasting habitats established during past riverine dynamics prior to installation of dams still is of ecological value to organisms. Contrasting habitats on other riverine floodplains promote increased abundance and diversity of vertebrates, including herpetofauna (Tockner et al. 1999, Tockner et al. 2006, Bateman et al. 2008a, b). Future management needs to recognize the importance of both woodlands and grasslands along the central Platte River because survival of both common and rare species is linked to other native species in the region.

Acknowledgments We thank The Crane Trust and Trevor Johnson for allowing access to their land to conduct this research. We thank Mary Harner and Mark Morten for logistical support at The Crane Trust. We thank Mary Harner and two anonymous reviewers for comments on this manuscript. We thank Lisa Bridger for her support and encouragement throughout the project and Aric Buerer for assistance in the laboratory. 
Research was supported in part by the Undergraduate Research Fellows program and the Department of Biology at the University of Nebraska at Kearney (UNK). We thank the Institutional Animal Care Use Committee (IACUC) at UNK and Wayne Briner for logistical support and discussions about surgical procedures. This research was approved by the UNK IACUC (080211) and conducted under a Scientific and Educational Permit from the Nebraska Game and Parks Commission issued to K. Geluso.

\section{Literature Cited}

Allen RP. (1952) The Whooping Crane. Research Report 3, National Audubon Society, New York, NY. 246 pp.

Aronson JG. (1980) Observations of late fall migratory Sandhill Cranes, Platte River, Nebraska. Nebraska Bird Review 48: 20-21.

Austin JE, and Richert AL. (2001) A comprehensive review of observational and site evaluation data of migrant Whooping Cranes in the United States 1943-99. U.S. Fish and Wildlife Service Report, Grand Island, NE. 156 p.

Ballinger RE, Lynch JD, and Smith GR. (2010) Amphibians and Reptiles of Nebraska (Oro Valley, AZ: Rusty Lizard Press).

Bateman HL, Chung-MacCoubrey A, and Snell HL. (2008a) Impact of non-native plant removal on lizards in riparian habitats in the southwestern United States. Restoration Ecology 16: 180-190.

Bateman HL, Harner MJ, and Chung-MacCoubrey A. (2008b) Abundance and reproduction of toads (Bufo) along a regulated river in the southwestern United States: importance of flooding in riparian ecosystems. Journal of Arid Environments 72: 1613-1619.

Burger J, Zappalorti RT, Gochfeld M, Boarman WI, Caffrey M, Doig V, Garber SD, Lauro B, Mikovsky M, Safina C, and Saliva J. (1988) Hibernacula and summer den sites of Pine Snakes (Pituophis melanoleucus) in the New Jersey Pine Barrens. Journal of Herpetology 22: 425-433.

Carpenter CC. (1953) A study of hibernacula and hibernating associations of snakes and amphibians in Michigan. Ecology 34: 74-80.

Churchill TA, and Storey KB. (1992) Freezing survival of the garter snake Thamnophis sirtalis parietalis. Canadian Journal of Zoology 70: 99-105.

Costanzo JP. (1989) Effects of humidity, temperature, and submergence behavior on survivorship and energy use in hibernating garter snakes, Thamnophis sirtalis. Canadian Journal of Zoology 67: 2486-2492.

Currier PJ, and Davis CA. (2000) The Platte as a prairie river: a response to Johnson and Boettcher. Great Plains Research 10: 69-84.
Fogell DD. (2010) A Field Guide to the Amphibians and Reptiles of Nebraska (Lincoln, NE: Institute of Agriculture and Natural Resources, University of Nebraska-Lincoln).

Geluso K, and Harner MJ. (2013a) Nerodia clarkii clarkii (Gulf Saltmarsh Watersnake): Predation. Herpetological Review 44: 156-157.

Geluso K, and Harner MJ. (2013b) Reexamination of herpetofauna on Mormon Island, Hall County, Nebraska, with notes on natural history. Transactions of the Nebraska Academy of Sciences 33: 7-20.

Gregory PT. (1982) Reptilian Hibernation. In C. Gans (Editor), Biology of the Reptilia, Volume 13, Physiology D: Physiological Ecology, pp. 53-154. (New York: Academic Press).

Harner MJ, Opitz N, Geluso K, Tockner K, and Rillig MC. (2011) Arbuscular mycorrhizal fungi on developing islands within a dynamic river floodplain: an investigation across successional gradients and soil depth. Aquatic Sciences 73: 35-42.

Harvey DS, and Weatherhead PJ. (2006) Hibernation site selection by Eastern Massasauga Rattlesnakes (Sistrurus catenatus catenatus) near their northern range limit. Journal of Herpetology 40: 66-73.

Henszey RJ, Pfeiffer K, and Keough JR. (2004) Linking surfaceand ground-water levels to riparian grassland species along the Platte River in central Nebraska, USA. Wetlands 24: 665-687.

Johnson WC. (1994) Woodland expansion in the Platte River, Nebraska: patterns and causes. Ecological Monographs 64: 45-84.

Johnson WC, and Boettcher SE. (2000a). The presettlement Platte: wooded or prairie river? Great Plains Research 10: 39-68.

Johnson WC, and Boettcher SE. (2000b) The Platte as a wooded river: a response to Currier and Davis. Great Plains Research 10: 85-87.

Jones SM, Ballinger RE, and Nietfeldt JW. (1981) Herpetofauna of Mormon Island Preserve Hall County, Nebraska. The Prairie Naturalist 13: 33-41.

Kingsbury BA, and Coppola CJ. (2000) Hibernacula of the Copperbelly Water Snake (Nerodia erythrogaster neglecta) in southern Indiana and Kentucky. Journal of Herpetology 34: 294-298.

Nagel HG. (1981) Vegetation ecology of Crane Meadows. Report to the Nature Conservancy and the Platte River Whooping Crane Critical Habitat Maintenance Trust, Alda, NE. $69+$ $11 \mathrm{pp}$.

Naiman RJ, Decamps H, and Pollock M. (1993) The role of riparian corridors in maintaining regional biodiversity. Ecological Applications 3: 209-212.

National Research Council. (2005) Endangered and Threatened Species of the Platte River (Washington, D.C.: The National Academies Press). 
Patten, T.J. 2006. Spatial ecology and natural history of the western massasauga rattlesnake (Sistrurus catenatus tergeminus) in southeastern Nebraska. M.S. Thesis, University of Nebraska at Omaha.

Pregitzer KS, and Friend AL. (1996) The structure and function of Populus root systems. In RF Stetler, HD Bradshaw Jr, PE Heilman, and TM Hinckley (Editors), Biology of Populus and its Implications for Management and Conservation, pp. 331-354. (Ottawa, Ontario: NRC Research Press, National Research Council of Canada).

Preston DL, Mosley CAE, and Mason RT. (2010) Sources of variability in recovery time from methohexital sodium anesthesia in snakes. Copeia 2010: 496-501.

Prior KA, and Weatherhead PJ. (1996) Habitat features of Black Rat Snake hibernacula in Ontario. Journal of Herpetology 30: 211-218.

Reinert HK, and Cundall D. (1982) An improved surgical implantation method for radio-tracking snakes. Copeia 1982: 702-705.

Rossman DA, Ford NB, and Seigel RA. (1996) The Garter Snakes: Evolution and Ecology. (Norman, OK: University of Oklahoma Press).

Schneider R, Stoner K, Steinauer G, Panella M, and Humpert M. (2011) The Nebraska Natural Legacy Project: State Wildlife Action Plan. $2^{\text {nd }}$ Edition. (Lincoln, NE: The Nebraska Game and Parks Commission).
Storey KB. (2006) Reptile freeze tolerance: metabolism and gene expression. Cryobiology 52: 1-16.

Tockner K, and Stanford JA. (2002) Riverine flood plains: present state and future trends. Environmental Conservation 29: 308-330.

Tockner K, Schiemer F, Baumgartner C, Kum G, Weigand E, Zweimuller I, and Ward JV. (1999) The Danube restoration project: species diversity patterns across connectivity gradients in the floodplain system. Regulated Rivers: Research and Management 15: 245-258.

Tockner K, Klaus I, Baumgartner C, and Ward JV. (2006) Amphibian diversity and nestedness in a dynamic floodplain river (Tagliamento, NE-Italy). Hydrobiologia 565: 121-133.

Van Pelt R., O'Keefe TC, Latterell JJ, and Naiman RJ. (2006) Riparian forest stand development along the Queets River in Olympic National Park, Washington. Ecological Monographs 76: 277-298.

Whited DC, Lorang MS, Harner MJ, Hauer FR, Kimball JS, and Stanford JA. (2007) Climate, hydrologic disturbance, and succession: drivers of floodplain pattern. Ecology 88: 940-953. 